\title{
Pemanfaatan Paket ddp di Software R untuk Analisis Pola Pangan Harapan
}

\section{The Application of ddp R Package for Desirable Dietary Pattern Analysis}

\author{
Weksi Budiaji*1,2 $^{*}$, Rifqi Ahmad Riyanto ${ }^{1}$, Suherna $^{1}$
}

\begin{abstract}
ABSTRAK
Latar Belakang: Pola Pangan Harapan (PPH) adalah susunan keberagaman bahan makanan atau kelompok bahan makanan yang didasarkan pada sumbangan energi. Skor PPH mendekati 100 dapat diartikan bahwa komposisi pangan sangat beragam. Badan Ketahanan Pangan RI (BKP) dan Nutrisurvey mengembangkan perhitungan skor PPH. Paket ddp di software R sebagai alternatif software juga bermanfaat untuk perhitungan skor PPH.

Tujuan: Menggunakan paket ddp di software R untuk perhitungan dan analisis PPH individu baik analisis deskriptif maupun analisis inferensia dan membandingkan perhitungan PPH pada paket ddp dengan software aplikasi harmonisasi analisis PPH Susenas dan Nutrisurvey.

Metode: Penelitian dilakukan dengan metode survey dan simulasi. Survey dilakukan pada mahasiswa program studi Teknologi Pangan Universitas Sultan Ageng Tirtayasa semester 3 secara online. Responden ditanya tentang pola makan dan menu makan dalam satu hari. Perhitungan dan analisis PPH dilakukan pada data yang valid dengan menggunakan paket ddp di Software R. Analisis PPH menggunakan analisis deskriptif dan inferensia yaitu uji t dan regresi linear sederhana.

Hasil: Paket ddp memerlukan waktu yang lebih lama yaitu 7 menit untuk memasukkan data menu seorang responden dalam satu hari dibandingkan Software Nutrisurvey yang membutuhkan waktu hanya 5 menit. Hasil analisis PPH dari paket ddp sama dengan hasil aplikasi harmonisasi analisis PPH Susenas, tetapi berbeda dengan Nutrisurvey karena pada Nutrisurvey ada kategori bahan makanan yang tidak masuk dalam database. Analisis deskripsi dan inferensia pada data responden sebagai analisis lanjutan dapat dilakukan dengan mudah. Analisis deskripsi menunjukkan bahwa mayoritas responden memiliki nilai energi, protein, lemak, dan karbohidrat yang rendah, dan variabel pengeluaran untuk pangan lebih dari $70 \%$ yang berpengaruh terhadap skor PPH adalah hasil dari analisis inferensia.

Kesimpulan: Skor PPH yang dihasilkan dari paket ddp memiliki keunggulan yaitu analisis lanjutan yang dapat dengan mudah dilakukan baik analisis deskriptif maupun analisis inferensia. Paket ddp dapat digunakan untuk perhitungan dan analisis PPH dengan baik dan memiliki hasil yang sama dengan aplikasi harmonisasi analisis PPH susenas. Walaupun proses penggunaan ddp memerlukan waktu yang lebih lama dibandingkan dengan Nutrisurvey, sumber data dari paket ddp lebih tepat dan cocok untuk perhitungan dan analisis skor PPH di Indonesia.
\end{abstract}

Kata kunci: Skor Pph, Paket Ddp, Software R, Pola Makan

\section{ABSTRACT}

Background: Desirable dietary pattern (DDP) is a variety of food nutrition intake that is calculated based on energy (calory) consumption. A DDP index close to 100 has a meaning that the food intake varies. Badan Ketahanan Pangan RI (BKP) and Nutrisurvey have developed a DDP index calculation software. As an alternative, ddp package of $R$ software can be also calculated ddp index.

Objectives: To apply the ddp package of Software R in calculating and analyzing DDP of individuals both descriptive and inferential analyses and to compare the ddp package with the application of PPH Susenas and Nutrisurvey Software.

Methods: This research applied survey and simulation methods. The survey was conducted on the 3rd-semester students of the Food Technology Department, University of Sultan Ageng Tirtayasa via an online survey. They administered both closed questions about dietary patterns and opened questions of a list of their daily food intake. Calculation and analysis of the DDP applied in the valid data in the ddp package of software $R$. The DDP analyses were followed by both descriptive and inferential analyses including t-test and simple linear regression.

Results: The ddp packaged required 7 minutes to input the menu data of each person per day. Compared to Nutrisurvey, it required only 5 minutes. There were different results between the ddp package and Nutrisurvey because a category of food could absent

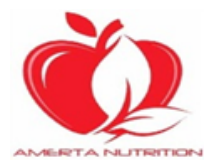

(C)2021. Budiaji, Rifqi Ahmad Riyanto dan Suherna. Open access under CC BY - SA license.

Received: 15-10-2020, Accepted: 29-03-2021, Published online: 01-09-2021.

doi: 10.20473/amnt.v5i3.2021. 303-312. Joinly Published by IAGIKMI \& Universitas Airlangga 
in the Nutrisurvey databases. The harmonization application of the DDP analysis Susenas, on the other hand, had similar results. Both descriptive and inferential analyses as a further analysis can be applied easily. The descriptive analysis showed that the majority of respondents had a low value of energy, protein, and carbohydrate, while the inferential statistic resulted in that the food expenditure more than $70 \%$ significantly affected the DDP score.

Conclusions: The ddp package could calculate and analyzed the DDP very well and had an equal result with the harmonization application of the DDP analysis susenas. Although the application process of the ddp package required a longer time than that of Nutrisurvey, the databases of the ddp package were more precise and suitable for the DDP calculation and analysis in Indonesia.

Keywords: ddp Score, ddp Package, R Software, Dietary Pattern

\author{
*Korespondensi: \\ budiaji@untirta.ac.id \\ Weksi Budiaji \\ ${ }^{1}$ Fakultas Pertanian, Universitas Sultan Ageng Tirtayasa \\ 2PUI-Ketahanan Pangan Universitas Sultan Ageng Tirtayasa \\ Jl. Raya Jakarta Km. 4 Pakupatan, Serang, Banten \\ Diterbitkan Oleh Universitas Airlangga dan IAGIKMI
}

\section{PENDAHULUAN}

Pendekatan pengukuran keragaman konsumsi pangan di Indonesia yang umum dilakukan menggunakan Pola Pangan Harapan (PPH). PPH adalah susunan beragam bahan makanan atau kelompok bahan makanan yang didasarkan pada sumbangan energi, baik secara absolut maupun relatif terhadap total energi, yang mampu memenuhi kebutuhan konsumsi pangan penduduk baik kuantitas, kualitas maupun keragaman dengan mempertimbangkan aspek sosial, ekonomi, budaya, agama, dan citarasa ${ }^{1}$. PPH juga dapat diartikan sebagai komposisi kelompok pangan utama yang sesuai dengan daya terima yang bila pangan tersebut dikonsumsi dapat memenuhi energi dan zat lainnya ${ }^{2}$.

PPH merupakan salah satu instrumen yang dapat digunakan untuk menilai mutu gizi konsumsi pangan kelompok baik jumlah maupun komposisi pangan menurut jenis pangan yang dinyatakan dalam skor ${ }^{1}$. PPH disimbolkan dengan sebuah skor dengan nilai maksimal 100. Jika nilai skor PPH mendekati 100 dapat diartikan bahwa komposisi pangan sangat beragam. PPH dapat juga digunakan untuk menilai mutu gizi konsumsi pangan pada tingkat individu ${ }^{3,4}$, rumah tangga ${ }^{5}$, dan wilayah ${ }^{6,7}$ sehingga pola konsumsi pangan masyarakat dapat di evaluasi. Kebutuhan pangan tingkat regional dan nasional juga dapat direncanakan.

Penghitungan skor PPH menggunakan data jumlah konsumsi energi per kelompok pangan yang memiliki karakter spesifik lokasi. Karakter ini menjadi dasar bahwa pembagian keragaman dari Badan Ketahanan Pangan RI lebih tepat digunakan untuk perhitungan PPH di Indonesia. Proporsi konsumsi energi untuk kelompok pangan dapat dibagi menjadi (1) Padi-padian 50\%, (2) Umbi-umbian 6\%, (3) Pangan hewani 12\%, (4) Minyak dan lemak 10\%, (5) Buah dan biji berminyak 3\%, (6) Kacang-kacangan 5\%, (7) Gula 5\%, (8) Sayur dan buah $6 \%$, serta (9) Lain-lain (bumbu) 3\%. Perkalian proporsi energi dari tiap kelompok pangan dengan pembobot diperoleh skor $\mathrm{PPH}^{1}$.

Badan Ketahanan Pangan RI mengembangkan perhitungan dengan bantuan MS Excel 8,9 yaitu aplikasi harmonisasi analisis PPH susenas. Penggunaan MS Excel yang merupakan software berbayar dan informasi dengan banyak lembar (sheets) di dalam perhitungan membuat perhitungan dengan software ini kurang ramah terhadap pengguna. Software Nutrisurvey juga dapat digunakan untuk menghitung PPH. PPH usia dewasa di Indonesia dapat dihitung dengan menggunakan software ini ${ }^{10}$. Dengan menambah data base, software ini dapat digunakan untuk spesifik lokasi kecuali data base lokasi yang diinginkan belum ada datanya. Jika perhitungan PPH dilakukan di platform bukan Windows, Nutrisurvey tidak dapat dijalankan.

Alternatif software gratis dan dapat dijalankan di Windows, Linux, maupun MacOs adalah software $\mathrm{R}{ }^{11}$. Kelebihan software $R$ adalah hasil penelitian dapat dengan mudah di reproduksi ulang untuk menjamin pengembangan keilmuan berkelanjutan 12-14 karena merupakan bahasa pemograman. Dukungan komunitas yang membuat paket-paket $\mathrm{R}$ dan dapat diunduh dengan gratis juga menjadi bagian paling penting dari kelebihan software R. Sebuah paket yang bermanfaat untuk perhitungan PPH adalah paket ddp yang dibuat untuk perhitungan PPH di Indonesia ${ }^{15}$.

Beberapa penelitian yang melibatkan perhitungan $\mathrm{PPH}$ dan analisis kalori di Indonesia menggunakan nutrisurvey sebagai alat bantu analisis ${ }^{16-19}$. Perhitungan dengan bantuan MS Excel pada penelitian PPH juga dapat dilakukan 20,21. Berbeda dengan sofware $R$ yang lebih dikenal sebagai software statistik, penggunaan software ini untuk perhitungan atau analisis $\mathrm{PPH}$ belum pernah dilakukan, padahal sangat mungkin $\mathrm{R}$ diaplikasikan pada perhitungan PPH. Artikel ini akan membahas penggunaan software R khususnya paket ddp pada kasus riil untuk perhitungan dan analisis (deskriptif dan inferensia) PPH. 


\section{METODE}

Penelitian ini adalah penelitian survey dan simulasi. Survey dilakukan dengan populasi mahasiswa Program Studi Teknologi Pangan semester 3 Universitas Sultan Ageng Tirtayasa. Pertimbangan menggunakan populasi mahasiswa Program Studi Teknologi Pangan semester 3 karena anggota populasi diasumsikan memahami komposisi dan gizi dari bahan pangan serta dapat mengakses internet dengan baik. Sampel diperoleh dari populasi secara purposif (sengaja) dengan jumlah 15 mahasiswa. Jumlah 15 tidak diambil dengan rumus tertentu, melainkan diperoleh dari jumlah mahasiswa yang merespon kuisioner on line yang telah disebar tautannya.

Kuisioner on line yang berikan kepada responden memiliki dua bagian yaitu bagian pertanyaan tertutup dan pertanyaan terbuka. Pertanyaan tertutup merupakan pertanyaan persepsi reponden terhadap pola pangan secara umum dengan format data likert 7 skala 22 . Pertanyaan terbuka berupa pertanyaan tentang menu pangan yang dimakan pada hari pengisian kuisioner yaitu menu makan pagi, siang, dan sore.

Data hasil kuisioner digunakan untuk simulasi penerapan software $\mathrm{R}$ dengan menggunakan paket ddp. Paket ddp pada software $\mathrm{R}$ digunakan untuk menganalisis total kalori dan skor PPH. Total kalori dihitung dengan menggunakan sebuah kode (fungsi) yaitu kalori sedangkan skor PPH diperoleh dengan menjalankan fungsi skorpph di $\mathrm{R}^{15}$. Kedua fungsi ini akan diterapkan pada data hasil isian kuisioner.

Fungsi kalori memiliki dua argumen, yaitu data dan output. Argumen data diisi dengan data yang akan dianalisis total kalorinya, sedangkan output digunakan untuk memunculkan total kalori yang dikonsumsi. Ada empat kemungkinan output yang dapat dimunculkan yaitu kalori protein, lemak, karbohidrat, dan total energi. Keempat kalori tersebut dapat dimunculkan secara bersama-sama jika argumen output diisi dengan all.

Fungsi skorpph mempunyai tiga argumen yaitu data, wilayah, dan baseline. Argumen data diisi dengan data yang akan dianalisis skor pphnya. Argumen wilayah digunakan untuk memasukkan asal provinsi responden. Jika wilayah ini diisi dengan Indonesia, maka skor pph nasional yang digunakan sebagai dasar perhitungan. Nilai baseline yang digunakan adalah 2000 kalori karena 2000 kalori adalah minimal kalori yang dibutuhkan orang Indonesia.

Analisis data dengan paket ddp dilakukan setelah melewati proses validasi data. Tahapan analisis kalori dan skor pph di software $\mathrm{R}$ dengan paket ddp adalah sebagai berikut:

1. Data isian responden dicek.

2. Data responden dibuat dalam bentuk 218 kolom dan $\mathrm{n}$ baris (Gambar 1), dengan kolom pertama adalah nama responden. Kolom ke-2 sampai dengan kolom ke-218 adalah jenis bahan pangan. Langkah ini adalah langkah validasi data untuk membentuk format data agar sesuai dengan format di paket ddp.

\begin{tabular}{|llllll|}
\hline $\begin{array}{l}\text { Nama } \\
\text { Nama 1 }\end{array}$ & 1 & 2 & $\ldots$ & 217 \\
Nama n & & & & & \\
Nam & & & & & \\
\hline
\end{tabular}

Gambar 1. Format Data

3. Masukkan data ke sistem $\mathrm{R}$.

4. Hitung energi dan skor pph dengan paket ddp.

5. Analisis data dengan analisis deskriptif dan/ atau inferensia. Analisis deskriptif tidak melibatkan uji/ test ${ }^{23}$ yaitu menggunakan plot dua komponen utama pertama (biplot), sedangkan inferensia ada uji yang diterapkan yaitu uji t. Variabel yang berbeda nyata diregresikan untuk dilihat pengaruhnya terhadap skor pph.

\section{HASIL DAN PEMBAHASAN}

\section{Karakteristik Responden}

Pengecekan awal jumlah responden menunjukkan bahwa ada dua responden yang menginput dua kali, sehingga jumlah responden menjadi 14 responden. Responden memiliki minimal 3 anggota keluarga dan maksimal 6 anggota dengan nilai tengahnya (median) adalah 5 anggota keluarga (Tabel 1 ). 
Tabel 1. Karakteristik Responden

\begin{tabular}{llc}
\hline \multicolumn{1}{c}{ Variabel } & \multicolumn{1}{c}{ Keterangan } & Frekuensi \\
\hline Jumlah anggota keluarga & 3 orang & 2 \\
& 4 orang & 4 \\
& 5 orang & $4^{*}$ \\
& 6 orang & 4 \\
Usia & 19 tahun & 14 \\
Jenis Kelamin & Laki-laki & 1 \\
Pendapatan & Perempuan & 13 \\
& $1(<500.00)$ & 0 \\
& $2(500.00-999.000)$ & 1 \\
& $3(1.000 .000-1.999 .999)$ & 0 \\
& $4(2.000 .000-2.999 .999)$ & 3 \\
& $5(3.000 .000-4.500 .000)$ & $4 *$ \\
& $6(>4.500 .000)$ & 6 \\
\hline
\end{tabular}

*cetak tebal adalah kategori yang memiliki nilai median.

Usia responden seragam yaitu 19 tahun yang mayoritas berjenis kelamin perempuan. Kategori pendapatan keluarga responden bervariasi dengan pendapatan terendah adalah kelas 2 (Rp 500.000 - Rp 999.999 per bulan) dan ada yang berpendapatan di kelas tertinggi (lebih dari Rp 4.500.000 per bulan). Pada kelas pendapatan keluarga, kategori pendapatan memiliki median pada kelas pendapatan 5 ( $R p$ 3.000.000-Rp 4.500.000 per bulan).

Format skala likert 7 skala dapat menggunakan nilai 4 sebagai nilai cut point untuk menjadi 2 kategori 24 . Item pertanyaan bahwa responden makan buah tiap hari, susu tiap hari, dan sering makan makanan siap saji menunjukkan bahwa responden jarang makan buah dan minum susu setiap hari (Tabel 2). Mayoritas responden juga jarang makan makanan siap saji. Item pertanyaan pola makan responden, makan tiga kali sehari, dan pengeluaran untuk makan lebih dari $70 \%$ dari pendapatan menunjukkan bahwa mayoritas responden sudah cukup karena berada pada nilai tengahnya yaitu 4 . Pertanyaan kepada responden tentang makanan responden yang telah bergizi, berimbang, dan beragam, kebersihan makanan yang terjamin, sering makan makanan olahan sendiri, dan makan sayur tiap hari menunjukkan bahwa mayoritas responden sudah sangat baik karena nilai mediannya lebih dari 4.

Tabel 2. Sebaran Jawaban Responden

\begin{tabular}{|c|c|c|c|c|c|c|c|}
\hline Pertanyaan & $\begin{array}{c}1 \\
\text { (Sangat tidak setuju) }\end{array}$ & 2 & 3 & 4 & 5 & 6 & $\begin{array}{c}7 \\
\text { (Sangat setuju) }\end{array}$ \\
\hline Saya makan 3 kali sehari & 0 & 3 & 1 & 4* & 4 & 0 & 2 \\
\hline Pola makan saya teratur & 2 & 2 & 1 & $4 *$ & 4 & 0 & 1 \\
\hline Makanan saya telah bergizi, berimbang, dan beragam & 0 & 1 & 3 & 1 & 7* & 2 & 0 \\
\hline Saya makan buah tiap hari & 2 & 2 & $4^{*}$ & 3 & 2 & 1 & 0 \\
\hline Saya makan sayur tiap hari & 1 & 0 & 1 & 4 & $\mathbf{2}^{*}$ & 4 & 2 \\
\hline Saya minum susu tiap hari & 4 & 2 & $4^{*}$ & 3 & 1 & 0 & 0 \\
\hline Saya sering makan makanan siap saji & 1 & 2 & 5* & 2 & 4 & 0 & 0 \\
\hline Makanan saya terjamin kebersihannya & 0 & 0 & 2 & 1 & 2 & $6^{*}$ & 3 \\
\hline Saya sering makan makanan olahan sendiri (tidak jajan) & 0 & 0 & 1 & 3 & 2 & $6^{*}$ & 2 \\
\hline $\begin{array}{l}\text { Pengeluaran untuk makan saya adalah lebih dari } 70 \% \\
\text { dari pengeluaran tiap bulan }\end{array}$ & 1 & 2 & 1 & 6* & 4 & 0 & 0 \\
\hline
\end{tabular}

*cetak tebal adalah kategori yang memiliki nilai median.

\section{Menu Responden}

Pertanyaan terbuka tentang menu makanan yang diisi responden dikonversi menjadi kode kelompok makanan sangat diperlukan agar sesuai dengan format data di paket ddp. Menu makanan responden dapat dikonversi kedalam 217 kelompok makanan sesuai dengan klasifikasi kementerian pertanian. Salah satu responden yaitu responden nomor 6 dan 15 memiliki menu nasi shirataki yang belum terdaftar pada 217 kelompok makanan tersebut (Tabel 3). Kekurangan daftar nasi shirataki ini juga terjadi pada paket ddp, sehingga untuk pengembangan paket ddp lebih lanjut kategori ini dapat dimasukkan secara spesifik agar perhitungan kalori lebih tepat. 
Tabel 3. Isian Responden Nomor 2, 6, dan 15

\begin{tabular}{ccll}
\hline Responden & Nama & \multicolumn{1}{c}{ Menu Pagi } & Menu Siang \\
\hline 2 & A1 & $\begin{array}{l}\text { nasi (150 gr), sayur selada air }(100 \mathrm{gr}), \text { telur } \\
\text { goreng (50 gr) }\end{array}$ & tidak makan siang \\
6 & A6 & $\begin{array}{l}\text { 1 lembar roti tawar dan 1 sdm madu } \\
\text { 1 lembar roti tawar dan 1 sdm madu }\end{array}$ & nasi shirataki (100gr) dan lele goreng (1 ekor) \\
nasi shirataki (100gr) dan lele goreng (1 ekor)
\end{tabular}

Data divalidasi untuk mengecek data yang tidak valid, misalnya responden nomor 6 dan 15 mengisi dua kali (Tabel 3). Responden yang memiliki menu yang tidak masuk kedalam 217 kategori juga dianggap tidak valid, seperti nasi shirataki, sehingga data yang telah valid terdiri atas 13 responden (responden nomor 6 dan 15 dihapus). Responden dengan respon yang valid kemudian dibuat menjadi data berformat/ berdimensi $13 \times 217$ agar sesuai dengan format paket ddp. Proses pengkonversian ini membutuhkan ketelitian dan waktu yang tidak singkat karena menu makanan yang berupa pertanyaan terbuka dikonversi kedalam 217 kolom kelompok makanan. Tiap

\section{Integrasi data ke sistem $\mathbf{R}$}

Data dimasukkan kedalam lingkungan $R$ dengan menggunakan kode read.table. Jika data telah masuk, paket ddp dapat dipakai dengan menggunakan kode isian pertanyaan terbuka menu responden dalam satu hari membutuhkan waktu kurang lebih 7 menit untuk dikoversi. Proses ini menjadi semakin lama sebanding dengan menu makanan yang direkam, misalnya pengkonversian menu makanan seorang responden seminggu lebih lama dibandingkan dengan jumlah menu makanan pada sehari saja. Beberapa studi yang menggunakan nutrisurvey ${ }^{16-19}$ tidak menyebutkan berapa lama waktu yang dibutuhkan untuk mendapatkan data per responden. Percobaan empiris dengan Nutrisurvey pada salah satu responen diperoleh bahwa tiap menu responden dalam sehari dapat dimasukkan kedalam software kurang lebih 5 menit.

library. Gambar 2 menunjukkan kode di software R yang dapat digunakan untuk memasukkan data (file data tersimpan di folder $\mathrm{C}$ dengan nama file data.txt). Baris library (ddp) untuk memanfaatkan fasilitas paket ddp.

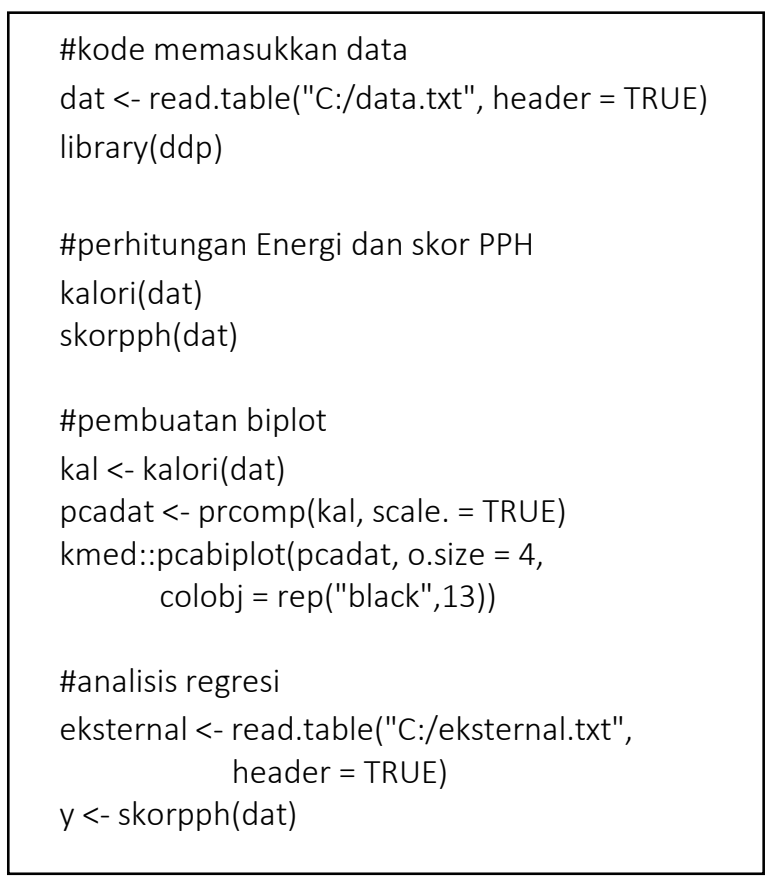

Gambar 2. Kode di Software R

Paket ddp yang terdiri atas fungsi memudahkan pengguna menghitung energi/ kalori dan skor PPH dari responden karena sebuah fungsi dapat merangkum banyak baris kode menjadi kode yang sederhana sehingga lebih mudah digunakan ${ }^{25}$. Fungsi dalam fungsi (nested function) juga dapat dibuat, tetapi kesalahan pada fungsi akan meyulitkan pendeteksiannya ${ }^{26}$. Perhitungan energi di paket ddp dapat menggunakan fungsi kalori, sedangkan skor PPH dapat diperoleh dengan fungsi skorpph (Gambar 2). Fungsi kalori menghasilkan empat nilai yaitu energi, protein, lemak, dan protein. Secara otomatis, fungsi kalori menghasilkan keempat nilai tersebut. Jika pengguna ingin

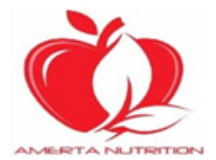

(C)2021. Budiaji, Rifqi Ahmad Riyanto dan Suherna. Open access under CC BY - SA license.

Received: 15-10-2020, Accepted: 29-03-2021, Published online: 01-09-2021.

doi: 10.20473/amnt.v5i3.2021. 303-312. Joinly Published by IAGIKMI \& Universitas Airlangga 
Tabel 4. Perbandingan Fungsi Kalori Semua Nilai dengan output=lemak

\begin{tabular}{|c|c|c|c|c|c|c|}
\hline No & Energi & Protein & Lemak & Karbohidrat & No & Lemak \\
\hline 1 & 1818 & 50 & 71 & 237 & 1 & 71 \\
\hline$\cdots$ & & & & & $\ldots$ & \\
\hline 6 & 961 & 23 & 10 & 189 & 6 & 189 \\
\hline$\ldots$ & & & & & $\ldots$ & \\
\hline 13 & 3049 & 108 & 108 & 383 & 13 & 108 \\
\hline
\end{tabular}

Tabel 4 adalah tabel perbandingan hasil perhitungan semua nilai kalori dibandingkan dengan hanya nilai lemak. Fungsi skorpph menghasilkan nilai PPH semua responden (Gambar 3). Nilai tertinggi skor PPH adalah 79 yang dimiliki oleh 4 orang responden. Ini menunjukkan bahwa keragaman pangan responden masih rendah

\begin{tabular}{|lll|}
\hline$[1] 79.00000$ & 72.14528 & 59.48325 \\
{$[4] 79.00000$} & 62.69490 & 79.24506 \\
{$[7] 69.71978$} & 59.00000 & 55.26419 \\
{$[10] 79.00000$} & 64.47802 & 61.31500 \\
{$[13] 76.43750$} & & \\
\hline
\end{tabular}

Gambar 3. Nilai Skor PPH 13 Responden

Nilai kalori dari 13 responden memiliki empat nilai yang terdiri atas energi, protein, lemak dan karbohidrat berbeda dengan hasil di Nutirsurvey. Hasil nutrisurvey tidak hanya empat nilai saja, tetapi menghasilkan analisis kalori yang lebih lengkap. Gambar 4 memperlihatkan contoh analisis kalori dari responden nomor 6 . Kelemahan dari Nutrisurvey adalah tidak tersedianya kategori makanan yang umum dimakan di Indonesia, misalnya jambu. Responden nomor 6 makan buah jambu pada hari pengambilan data, padahal kategori jambu tidak dapat ditemukan di database Nutrisurvey.
Berbeda dengan Nutrisurvey, aplikasi harmonisasi analisis PPH susenas dengan MS Excel dari BKP kementan 1,9 memiliki hasil yang sama dengan analisis paket ddp karena paket ddp dibuat berdasarkan perhitungan BKP Kementan. Tabel 5 menunjukkan perhitungan kalori responden nomor 6 yang sama dengan hasil dari paket ddp dengan fungsi kalori (Tabel 4). Perbedaannya adalah MS Excel perangkat lunak berbayar sedangkan $\mathrm{R}$ gratis. Pertimbangan lain menggunakan $\mathrm{R}$ adalah analisis lanjutan yang dengan mudah dikerjakan, misalnya analisis deskripsi hasil skor PPH atau analisis inferensia variabel yang berpengaruh terhadap skor PPH. 


$\begin{array}{lr}\text { Total analysis: } & \\ & \\ \text { energy } & 595,3 \mathrm{kcal} \\ \text { water } & 438,0 \mathrm{~g} \\ \text { protein (168) } & 22,8 \mathrm{~g} \\ \text { fat (178) } & 11,6 \mathrm{~g} \\ \text { carbohydr. (678) } & 98,1 \mathrm{~g} \\ \text { dietary fiber } & 5,9 \mathrm{~g} \\ \text { alcohol (08) } & 0,0 \mathrm{~g} \\ \text { purA } & 3,6 \mathrm{~g} \\ \text { cholesterol } & 191,0 \mathrm{mg} \\ \text { Vit. A } & 365,4 \mathrm{gg} \\ \text { carotene } & 1,1 \mathrm{mg} \\ \text { Vit. E (eq.) } & 2,9 \mathrm{mg} \\ \text { Vit. B1 } & 0,5 \mathrm{mg} \\ \text { Vit. B2 } & 0,3 \mathrm{mg} \\ \text { Vit. B6 } & 0,8 \mathrm{mg} \\ \text { tot. fol.acid } & 91,3 \mathrm{Mg} \\ \text { Vit. C } & 26,3 \mathrm{mg} \\ \text { sodium } & 64,4 \mathrm{mg} \\ \text { potassium } & 440,6 \mathrm{mg} \\ \text { calcium } & 161,9 \mathrm{mg} \\ \text { magnesium } & 330,3 \mathrm{mg} \\ \text { phosphorus } & 689,6 \mathrm{mg} \\ \text { iron } & 6,7 \mathrm{mg} \\ \text { zinc } & 3,4 \mathrm{mg} \\ & \end{array}$

Gambar 4. Analisis Kalori Responden Nomor 6 dengan Nutrisurvey

Tabel 5. Hasil Perhitungan Kalori dengan Aplikasi Harmonisasi Analisis PPH Susenas Responden Nomor 6

\begin{tabular}{|c|c|c|c|c|c|c|c|c|c|c|c|}
\hline \multirow[b]{2}{*}{ Menu } & \multirow[b]{2}{*}{ Bobot } & \multicolumn{5}{|c|}{ Standar } & \multicolumn{5}{|c|}{ Perhitungan } \\
\hline & & $\begin{array}{l}\text { Berat } \\
\text { (gram) }\end{array}$ & $\begin{array}{l}\text { Energi } \\
\text { (kkal) }\end{array}$ & $\begin{array}{c}\text { Protein } \\
\text { (gr) }\end{array}$ & $\begin{array}{c}\text { Lemak } \\
\text { (gr) }\end{array}$ & $\begin{array}{c}\text { Karbo } \\
\text { (gr) }\end{array}$ & proporsi & $\begin{array}{l}\text { Energi } \\
\text { (kkal) }\end{array}$ & $\begin{array}{c}\text { Protein } \\
\text { (gr) }\end{array}$ & $\begin{array}{c}\text { Lemak } \\
\text { (gr) }\end{array}$ & $\begin{array}{c}\text { Karbo } \\
\text { (gr) }\end{array}$ \\
\hline Telur ayam & 50 & 1,000 & 1,370 & 110 & 96.1 & 6.2 & 0.05 & 68.53 & 5.518 & 4.806 & 0.3115 \\
\hline Tahu & 60 & 1,000 & 800 & 109 & 47.0 & 8.0 & 0.06 & 48 & 6.54 & 2.82 & 0.48 \\
\hline Jeruk & 20 & 1,000 & 311 & 5 & 1.6 & 78.3 & 0.02 & 6.226 & 0.1058 & 0.032 & 1.566 \\
\hline Jambu & 20 & 1,000 & 441 & 5 & 2.9 & 110.9 & 0.02 & 8.836 & 0.1156 & 0.0584 & 2.218 \\
\hline Nasi putih & 400 & 200 & 391 & 4 & 0.2 & 89.3 & 2.00 & 783.2 & 9.24 & 0.44 & 178.64 \\
\hline \multirow[t]{2}{*}{ Sayur matang } & 50 & 250 & 232 & 9 & 8.0 & 30.0 & 0.20 & 46.5 & 1.924 & 1.604 & 6.008 \\
\hline & & & & & & & & 961.292 & 23.4434 & 9.7604 & 189.2235 \\
\hline
\end{tabular}

\section{Analisis deskripsi}

Nilai skor PPH sebagai instrumen untuk melihat keragaman pangan responden secara keseluruhan belum dapat menggambarkan karakteristik (posisi) tiap individu terhadap individu lain. Karakteristik ini dapat dideskripsikan dengan bantuan plot dua dimensi yaitu biplot. Biplot dapat dibuat dengan bantuan paket kmed 27,28 (Gambar 2) dengan menuliskan kmed::pcabiplot. Plot yang dihasilkan adalah plot dua komponen utama pertama dari dekomposisi keempat variabel kalori. Biplot komponen utama menghasilkan posisi semua responden dengan tambahan garis yang merepresentasikan korelasi dan keragaman variabel (Gambar 5). 


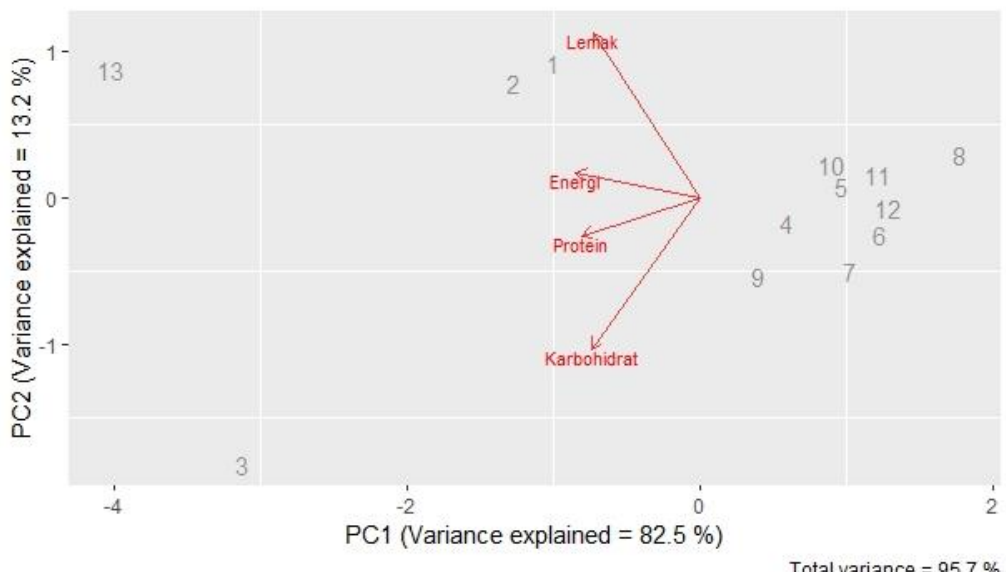

Gambar 5. Biplot Dua Komponen Utama

Gambar 5 menunjukkan bahwa biplot memiliki total keragaman yang baik (95.7\%) yang berarti $96 \%$ keragaman data dapat terwakili dalam biplot. Sudut antar garis menunjukkan korelasi antar variabel ${ }^{29}$ dengan karbohidrat dan lemak keduanya memiliki korelasi positif yang paling kecil karena keduanya membentuk sudut yang paling lebar. Korelasi positif paling tinggi dimiliki antara energi dengan protein dan energi dengan lemak (keduanya bersudut sempit).

Tanda panah dari setiap garis berarti bahwa individu yang searah dengan garis variabel tersebut secara orthogonal (tegak lurus) terhadap garis memiliki nilai yang positif. Responden nomor 1 dan 2 memiliki nilai yang sama pada lemak karena keduanya secara orthogonal berada diwilayah positif garis lemak (berimpit). Responden nomor 2 lebih baik dari responden nomor 1 pada energi karena secara orthogonal responden nomor 2 berada diwilayah yang lebih positif daripada responden nomor 1 pada garis energi.

Gambar 5 juga menunjukkan bahwa sebagian besar responden memiliki nilai energi, protein, lemak, dan karbohidrat yang rendah. Sebagian besar posisi responden terletak diwilayah negatif dari keempat garis variabel. Hanya empat responden yaitu responden nomor 1, 2, 3, dan
13 yang memiliki nilai positif.

\section{Analisis inferensia}

Analisis inferensia dapat dilakukan untuk menyimpulkan populasi. Mahasiswa yang mengisi kuisioner adalah mahasiswa yang diambil secara purposif, sehingga tidak mewakili populasi mahasiswa studi. Jika diasumsikan bahwa sampel yang diambil adalah mahasiswa yang mewakili populasi maka analisis skor pph dapat dilanjutkan dengan analisis inferensia.

Data variabel eksternal yaitu selain data penyusun skor PPH responden juga tersedia. Data tersebut adalah data pertanyaan tertutup (Tabel 2). Variabel pada Tabel 2 adalah variabel dengan 7 respon dengan 1 adalah sangat tidak setuju dan 7 adalah sangat setuju. Semua variabel kemudian di buat menjadi binary dengan cara yang sederhana yaitu dengan cut point median ${ }^{24}$ (4). Nilai 1 sampai 3 menjadi 0 dan 4 sampai dengan 7 menjadi 1 . Skor pph diuji $t$ dengan kesepuluh variabel pertanyaan yang telah dibuat menjadi binary. Hasil nilai $p$ yang diperoleh menunjukkan hanya pengeluaran untuk pangan $70 \%$ yang berbeda nyata (Tabel 6).

Tabel 6. Nilai t Hitung dan Nilai p Kesepuluh Variabel

\begin{tabular}{lcc}
\hline Variabel & t hitung & Nilai $p$ \\
\hline Saya makan 3 kali sehari & 0.09 & 0.93 \\
Pola makan saya teratur & -1.28 & 0.23 \\
Makanan saya telah bergizi, berimbang, dan beragam & 0.09 & 0.93 \\
Saya makan buah tiap hari & 1.42 & 0.19 \\
Saya makan sayur tiap hari & -1.77 & 0.19 \\
Saya minum susu tiap hari & 0.75 & 0.49 \\
Saya sering makan makanan siap saji & -0.15 & 0.88 \\
Makanan saya terjamin kebersihannya & 0.56 & 0.65 \\
Saya sering makan makanan olahan sendiri (tidak jajan) & - & $-* *$ \\
Pengeluaran untuk makan saya adalah lebih dari 70\% dari pengeluaran tiap bulan & -3.35 & $0.01^{*}$ \\
\hline
\end{tabular}

* berbeda nyata pada taraf 5\%

** tidak dapat dihitung karena salah satu grup (diatas/ dibawah nilai median) hanya terdiri atas 1 responden

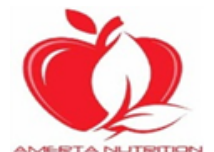

(C2021. Budiaji, Rifqi Ahmad Riyanto dan Suherna. Open access under CC BY - SA license.

Received: 15-10-2020, Accepted: 29-03-2021, Published online: 01-09-2021. doi: 10.20473/amnt.v5i3.2021. 303-312. Joinly Published by IAGIKMI \& Universitas Airlangga 
Analisis regresi diterapkan pada skor PPH dengan menggunakan variabel pengeluaran untuk makan lebih dari $70 \%$. Analisis regresi linear sederhana ini digunakan untuk menyimpulkan seberapa besar pengaruh variabel terhadap skor PPH. Gambar 2 memiliki kode untuk analisis regresi dengan variabel terikat adalah skor PPH sedangkan variabel bebasnya adalah persetujuan atas $70 \%$ pengeluaran pada makanan (nominal).

Analisis regresi menghasilkan kesimpulan bahwa coefficients:

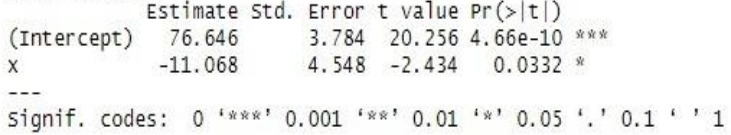

Gambar 6. Hasil Analisis Regresi

Analisis deskripsi dan inferensia pada data 15 responden menggunakan software $\mathrm{R}$ yang merupakan bahasa sumber dari paket ddp sehingga kelebihan software $R$ yaitu kemudahan direproduksi ulang ${ }^{12-14}$ juga dimiliki paket ddp. Dengan sumber data dari aplikasi harmonisasi PPH Susenas, hasil analisis paket ddp juga sangat sesuai dan cocok dengan skor PPH di Indonesia. Meskipun analisis inferensia dapat dilakukan pada jumlah responden 15 orang, pengambilan kesimpulan menjadi lemah karena diperlukan sampel data yang cukup dan mewakili untuk kesimpulan populasi. Bertambahnya jumlah responden akan berakibat pada penambahan waktu konversi pertanyaan menu makanan (yang biasanya merupakan pertanyaaan terbuka) kedalam 217 kelompok makanan. Selisih waktu untuk konversi 15 responden pada paket ddp adalah $\mathbf{3 0}$ menit lebih lama dibandingkan dengan software Nutrisurvey, artinya semakin banyak responden yang terlibat, kelemahan waktu konversi menjadi semakin terlihat.

\section{KESIMPULAN}

Paket ddp dapat digunakan untuk analisis skor pph dan kalori. Paket ddp mudah digunakan, gratis, dan dapat direproduksi ulang, meskipun perlu dikembangkan lagi untuk daftar kelompok pangan yang belum ada. Pengguna paket ddp harus teliti karena proses konversi ke format data paket ddp ( $\mathrm{n}$ baris, 217 kolom) membutuhkan waktu 7 menit tiap responden per menu tiap hari. Walaupun proses penggunaan paket ddp memerlukan waktu yang lebih lama dibandingkan dengan Nutrisurvey, sumber data dari paket ddp lebih tepat dan cocok untuk perhitungan skor PPH di Indonesia. Skor PPH yang diperoleh pada paket ddp sama dengan aplikasi harmonisasi analisis PPH susenas yang menggunakan MS Excel. Keunggulan lain dari paket ddp adalah analisis lanjutan dapat dengan mudah dilakukan baik analisis deskriptif maupun analisis inferensia. variabel persetujuan atas $70 \%$ pengeluaran pada makanan berpengaruh nyata terhadap skor PPH responden (Gambar 6). Koefisien -11 menunjukkan bahwa jika responden setuju bahwa pengeluran mereka lebih dari $70 \%$ digunakan untuk makanan, maka skor PPH nya turun sebesar 11 skala. Hasil ini sesuai dengan konsep aksesibilitas (keterjangkauan) bahan pangan yang jika individu memiliki proporsi pengeluaran untuk bahan pangan yang semakin tinggi maka ketahanan pangannya semakin rentan 30 .

\section{ACKNOWLEDGEMENT}

Ucapan terima kasih kami sampaikan kepada Lembaga Penelitian dan Pengabdiaan kepada Masyarakat (LPPM) Universitas Sultan Ageng Tirtayasa (Untirta) yang telah mendanai penelitian ini melalui Hibah Penelitian Dasar Internal (PDI).

\section{REFERENSI}

1. BKP Kementan. Panduan Perhitungan Pola Pangan Harapan (PPH). (Badan Ketahanan Pangan Kementerian Pertanian, 2015).

2. Hardinsyah, R., B. D. ,. \&. Retnaningsih, H. T. ,. \&. Wijaya. Analisis Kebutuhan Konsumsi Pangan. (Pusat Studi Kebijakan Pangan Dan Gizi IPB Dan Pusat Pengembangan Konsumsi Pangan, Badan BIMAS Ketahanan Pangan, 2002).

3. DPPS Andadari, T. M. Keragaman Pangan dan Tingkat Kecukupan Energi serta Protein Pada Balita. Amerta Nutr. 1, 172-179 (2017).

4. Y Widodo, F. E., S. Sandjaja. Skorp Pola Pangan Harapan dan Hubungannya dengan Status Gizi Anak Usia 0,5 - 12 Tahun di Indonesia. Penelit. Gizi Dan Makanan 40, 63-75 (2017).

5. M Handayani, R. I., WD Sayekti. Pola Konsumsi Pangan Rumah Tangga pada Desa Pelaksana dan Bukan Pelaksana Program Percepatan Penganekaragaman Konsumsi Pangan (P2KP)di Kabupaten Pringsewu. J. IImu IImu Agribisnis 7, 28-35 (2019).

6. S Argandi, T. N., L. Trimo. Faktor-Faktor yang Memperngaruhi Pola Pangan Harapan (PPH) di Kabupaten Bandung. J. Agribisnis Terpadu 11, 126140 (2018).

7. D Deshaliman, A. G. Perencanaan Penyediaan Pangan Penduduk Ibukota Negara di Provinsi Kalimantan Timur Tahun 2024 Telaah Berbasis Pola Pangan Harapan. J. Pilar Ketahanan Pangan 1, 25-38 (2019). 
8. BKP Kementan. Aplikasi Analisis Konsumsi dan Perencanaan Pangan. (Badan Ketahanan Pangan Kementerian Pertanian, 2012).

9. BKP Kementan. Aplikasi Harmonisasi Analisis PPH Data Susenas 2017. (Badan Ketahanan Pangan Kementerian Pertanian, 2017).

10. Anwar, \& H., K. Konsumsi Pangan dan Gizi serta Skor Pola Pangan Harapan pada Dewasa Usia 19-49 Tahun di Indonesia. J. Gizi Dan Pangan 9, 51-68 (2014).

11. R Core Team. R: A Language and Environment for Statistical Computing. (R Foundation for Statistical Computing, 2015).

12. Peng, R. D. Reproducible research in computational science. Science 1226-1227 (2011).

13. Sarvina, $Y$. Pemanfaatan Software Open Source $R$ untuk Penelitian Agroklimat. Inform. Pertan. 26, 2330 (2017).

14. Budiaji, W. Penerapan Reproducible Research pada RStudio dengan Bahasa R dan Paket Knitr. Khazanah Inform. J. Ilmu Komput. Dan Inform. 5, 1-5 (2019).

15. Budiaji, W. ddp: desirable dietary pattern. (2020).

16. I Kusumastuty, S. M., LB Harti. Perbedaan Kandungan Serat Pangan pada Makanan Siap Saji Khas Indonesia yang Dianalisis dengan Menggunakan Nutrisurvey dan Enzimatik Gravimetri. Maj. Kesehat. FKUB 3, 196203 (2016).

17. D Handayani, W. R., N. Azizah, H. Hanifa. Densitas Energi dan Sajian Karbohidrat Makanan Tradisional dan Modern di Kota Malang. Indones. J. Hum. Nutr. 3, 11-18 (2016).

18. V Silalahio, T. A., E. Aritonang. Potensi Pendidikan Gizi dalam Meningkatkan Asupan Gizi pada Remaja Putri yang Anemia di Kota Medan. J. Kesehat. Masy. 11, (2016).

19. AB Haq, E. M. Status Gizi, Asupan Makan Remaja Akhir yang Berprofesi sebagai Model. J. Nutr. Coll. 3, 489494 (2014).
20. Priambodo, N. D. Analisis Neraca Bahan Makanan Kota Kediri Tahun 2018. AGRIOVET 1, 226-236 (2019).

21. R Winati, E. D., AH Yusra. Pola Pangan Harapan Petani Ubi Ungu di Desa Sungai Ambangah Kabupaten Kuburaya. in Kebijakan untuk Petani: Pemberdayaan untuk Pertumbuhan dan Pertumbuhan yang Memberdayakan 139-154 (Perhimpunan Ekonomi Pertanian Indonesia, 2014).

22. Budiaji, W. Skala Pengukuran dan Jumlah Respon Skala Likert. J. Ilmu Pertan. Dan Perikan. 2, 127-133 (2013).

23. Hutchinson S.R., C. D. L. A Review of Methodological Characteristics of Research Published in Key Journals in Higher Education: Implications for Graduate Research Training. Res. High. Educ. 45, 383-403 (2004).

24. Jamie DeCoster, A.-M. R. I., Marcello Gallucci. Best Practices for Using Median Splits, Artificial Categorization, and their Continuous Alternatives. J. Exp. Psychopathol. 2, 197-209 (2011).

25. Wickham, H. testthat: Get Started with Testing. $R$ J. 3, 5-10 (2011).

26. Angel Rubio, F. deVillar. Code Profiling in R: A Review of Existing Methods and an Introduction to Package GUIProfiler. R J. 7, 275-287 (2015).

27. Budiaji, W. Partitioning Clustering Algorithms in Food Security Mapping. (Universitat fur Bodenkultur Wien, 2019).

28. Budiaji, W. kmed: Distance-Based k-Medoids. (2019).

29. Daniel Torres-Salinas, E. D. L.-C., Nicolas RobinsonGarcia, Evaristo Jimenez-Contreras, Francisco Herrera. On the use of biplot analysis for multivariate bibliometric and scientific indicators. J. Am. Soc. Inf. Sci. Technol. 64, 1468-1479 (2013).

30. Imron Rosyadi, D. P. Tingkat Ketahanan Pangan Rumah Tangga di Desa Tertinggal. J. Ekon. Pembang. 13, 303-315 (2012). 